\title{
Vállt vállnak vetve - gyerekek a gyermekkorról
}

\section{ENDRŐdY OrSOLYA - LÉNÁRT ISTVÁN - IRINA MARKOVINA}

Eötvös Loránd Tudományegyetem Tanító- és Óvóképző Kar - Sechenov Egyetem, Moszkva Sechenov Egyetem, Moszkva

A 2018-ban megkezdett empirikus kutatásunk a 4-5 éves korosztály gyermekképének feltárását és nyelvi tudatosságának mélyebb megértését tüzte ki célul orosz és magyar gyermekek asszociációinak összehasonlitó, interdiszciplináris vizsgálatával. A kutatás alapvetöen a pszicholingvisztika és a koragyermekkor-kutatás határterületén vizsgálódik, mind módszertanilag, mind az elméleti háttér tekintetében a két diszciplina szoros együttmüködésével valósul meg. Módszertanunkat a shoulderto-shoulder (vállt vállnak vetve) (Griffin et al., 2014) és a szóasszociációs módszer felhasználásával alakitottuk ki, az elméleti háttérnél pedig a Moszkvai Pszicholingvisztikai Iskola valamint a Gyermekkor mint konstrukció paradigma tekinthetö kiindulási pontnak. A kutatást egy párhuzamosan Moszkvában és Budapesten dolgozó kutatócsoport végzi, mely a 4-5 éves korosztályt követöen már megkezdte a 10-12 évesek körében végzett felmérést is. A munkát az Orosz Alapkutatások Alapja (RFFI) támogatja. Jelen tanulmányunkban a kutatás módszertanára fókuszálunk.

Kulcsszavak: szóasszociáció, pszicholingvisztika, shoulder-to-shoulder (vállt vállnak vetve) módszer, gyermekkép, koragyermekkor

\section{Egy kultúraközi interdiszciplináris kutatás indulása}

Számos vizsgálat igyekszik feltárni egy-egy korszak, térség vagy társadalmi csoport nézeteit a gyermekkorról - például (EndrődyNagy, 2013; Aggné Pirka és Endrödy-Nagy, 2015, 2017a, b; Serföző és Böddi, 2018), ám ezek közül kevés kíváncsi arra, hogy mit gondolnak a gyermekek saját magukról, hogyan élik meg gyermekségüket, s hogyan definiálják magát a korszakot, amelyben felnőnek.

Ugyanígy évtizedek óta léteznek szóasszociációs szótárak (ld. 3.1.fejezet), melyek elsődleges célja egy-egy nemzet nyelvhasználóinak szókincsét minél alaposabban feltérképezni, s ennek részeként egyes szavak asszociációinak összegyüjtése. Ezeket a vizsgálatokat a kutatók anyanyelvi felnőtt nyelvhasználók lekérdezésével valósítják meg. Vajon a gyermekek ugyanazokat az asszociációkat kapcsolják egy-egy szóhoz, mint a felnőttek? Hogy kaphatunk képet a különféle nyelvi tudatosságról a gyermekek esetén? Melyik az a legfiatalabb korosztály, amelyik képes megérteni a vizsgálat kérdéseit és érdemi válaszokat adni?

A két látszólag távoli kutatási terület gyermekkorkutatás és pszicholingvisztika - a fenti kérdésfeltevések mentén rendkívül jól segít pontosabban megválaszolni a kérdéseket. Ám egy dologra minden pillanatban figyelemmel kell lennünk: a két kutatási területnek folyamatos egyensúlyban kell lennie, bármennyi nehézséggel is szembesülünk. Az 1. ábra ezt illusztrálja. Arról, hogyan érhető el az egyensúly, jelen tanulmányban a módszertan körüljárásával igyekszünk rávilágítani.

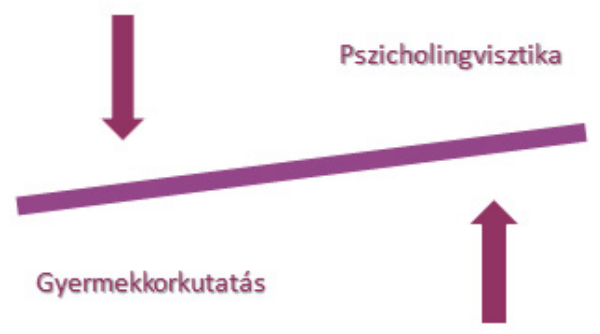

1. ábra: Kutatási területek egyensúlyának megteremtési nehézsége az interdiszciplináris kutatásban

\subsection{A kutatás céljai}

A kutatás egyediségét az adja, hogy a gyermekeket saját magukat kérjük meg definiálják saját világukat. A legfőbb cél, hogy megértsük a gondolkodásukat saját magukról, 
a gyermekkorról, elsődleges és másodlagos szocializációs színtereik fogalmi hátteréről, ezért a kutatás fö fókusza a 4-5 éves gyermekekkel felvett szóbeli kikérdezés a gyermekképük és nyelvi tudatosságuk megértésére irányulva.

A pszicholingvisztika szemszögéből nézve pedig további céljaink közt szerepel a korábbi szóasszociációs vizsgálatok életkori változó beemelésével történő árnyalása.

\section{Az interdiszciplináris kutatások jelentősége különös tekintettel a koragyermekkorra}

Az elmúlt évtizedekben folyamatosan növekszik az interdiszciplináris együttmüködések száma. Az interdiszciplináris együttmüködésekben minden tudományterület érintett. Két vagy több területen tevékenykedő kutató együttműködése segítheti a vizsgált jelenségek mélyebb megértését, bonyolultabb összefüggéseket tárhat fel, mint az egy diszciplináris területben elmélyedő kutatások (Frickel et al., 2017. 5. o.).

Az együtt dolgozó kutatók számára stimuláló és inspiráló lehet a kutatás témája, az újdonságként megismert elméleti háttér, a másik, vagy többiek által feltárt és gyakorlatban alkalmazott módszertan, vagy az eredmények újfajta megközelítése. Mindezek mellett fontos hangsúlyozni, hogy a kutatók kíváncsisága, nyitottsága és egymás területének tiszteletben tartása, fokozatos megismerése, a törékeny összhang megőrzése elsődlegesen befolyásolja a kutatás sikerességét. Ha a fenti kompetenciákkal mindkét, vagy az érintett összes fél rendelkezik, új perspektívákat és lehetséges új kutatási területet tárhatnak fel az együttműködő felek.

\subsection{Elméleti áttekintés}

\subsubsection{A gyermekkép mint konstrukció}

Elöljáróban, definicióként egyetértve Nóbik Attilával a következő meghatározást tekinthetjük kiindulásnak: "Gyermekkép alatt a gyermekről és a gyermek világáról való ismereteket, és az ahhoz kapcsolódó hozzáállást érthetjük." (Nóbik, 2000. 374. o.) A fejlődést mint kulcsfogalmat használó gyermekkor-értelmezések ma már nem elegendőek ahhoz, hogy a gyermeki lét minden elemét, velejáróját megértsük (Szabolcs, 2003). Újfajta nézőpontra van szükség, mely a hagyományos tudományossághoz kapcsolódó gyermekfogalmat lebontja, dekonstruálja, és a gyermekség interpretálása kapcsán egy olyan értelmezési keretet jelenít meg, mely a bevett, mindenki által elfogadott jellemzőktől eltávolodik (Golnhofer és Szabolcs, 2005. 68-69. o.). Canella nézetei szerint a dekonstruálás annyit tesz, hogy a hagyományosan megállapodott nézeteinket a gyermekkorral kapcsolatosan le kell bontani és más összefüggésbe helyezni, hogy ezáltal új értelmezések szülessenek (Golnhofer és Szabolcs, 2005). Canella elgondolása többek közt az, hogy a gyermekség különböző kulturális közegben mást és mást jelent, valamint, hogy a felnőtt-gyermek különbség konstruált, a felnőtt, azaz hatalmi szerepben levő felől közelíti a különbségeket. Az individuális gyermekre koncentrálva nem rajzolódnak ki a gyermeki nemhez, osztályhoz, kultúrához tartozó tudásegyüttesek (Golnhofer és Szabolcs, 2005, 71. o.). Angol szociológusok egy csoportja ezért a gyermekkort mint szociológiai fogalmat tekinti, azt vallva, hogy a gyermekkort a társadalom és kultúra részének, a gyermekeket pedig a társadalom szereplőinek, és nem csupán arra törekvőknek kell tekinteni (James és Prout, 1997).

A James, Prout, valamint Jenks által létrehozott paradigma három legfontosabb eleme a következő (James és Prout, 1997):

1. A gyermekkorfogalom társadalmilagszociológiailag konstruált. A gyermek - gyermekkorfogalom alatt minden társadalomban mást és mást értenek.

2. A gyermekkor fogalma adott társadalmi közegben is különféle lehet, figyelembe véve a nemet, a társadalmi osztályt és az etnikumot.

3. A gyermek aktív résztvevője és alakítója életének, és a környezete életét is befolyásolja.

Alderson 2013-ban megjelent Childhoods Real and Imagined címü munkájában kifejti, hogy a pozitivista szociológiai kutatások ter- 
Vállt vállnak vetve - gyerekek a gyermekkorról

mészettudományos kutatásokon alapulnak, szkeptikus a tudományos igazság, valamint az általános igazságok létezésével kapcsolatban (Alderson, 2013). Kifejti, hogy a biológiai terminusok, mint például a halál, társadalmi konstrukciót jelentenek. A társadalmi konstrukció véleménye szerint nem más, mint ahogy a kultúra formálja tapasztalatainkat, identitásunkat és kapcsolatainkat (Alderson, 2013. 33. o.).

Mindezen gondolatok összhangban vannak azzal a kijelentéssel, mely szerint a gyermekkorok térben és időben nagy változatosságot mutathatnak, tehát nem lehet egyetemes gyermekkorról beszélni (Szabolcs, 2003). Fontos hangsúlyozni, hogy az egyes ember élete során is változik a fogalmi koncepciója egy-egy területen. Mindenekelőtt azért fontos, hogy tudjuk: megközelítésmódunk csak egy a lehetségesek közül, hiába igyekszünk a kérdést több oldalról megvizsgálni, nem adhatunk teljes képet egy-egy korszak, térség vagy társadalmi csoport gyermekképről sem. Nagyon fontos az is, hogy a gyermekeket ne a felnőttekhez viszonyítva vizsgáljuk, hanem - Harry Hendrick fogalmával élve - társadalmi „aktor”-okként (Hendrick, 2000; Golnhofer és Szabolcs, 2005). Mindezért a kutatásban a gyermekek életét helyezzük reflektorfénybe, és nem hasonlítjuk össze a gyermekek életét a felnőttekével. Christiansen szerint a kép összeállítása csak úgy lehetséges, ha a szociális interakciót és az emberi kapcsolatokat az ő saját kódrendszerükön keresztül értelmezzük (Christiansen és James, 2000). Ráadásul Hendrick rámutat arra, hogy a gyermekek kénytelenek életük értelmezését egy másik korosztályra bízni, így az objektivitás érzékeny kérdése ismét előkerül (Golnhofer és Szabolcs, 2005. 43. o.). Szabolcs Éva jelzi, hogy a gyermekkorfogalom konstrukció, a felnőtt konstruálja a gyermekkor-fogalmát. (Szabolcs, 2003). A kutatásokban igény és elvárás, hogy a gyermekek világát ne felnőtttávolságtartással, felülnézetből vizsgáljuk ( $M e ́-$ száros, 2010). Éppen ezek miatt szükségesnek és jogosnak tünik, ha a gyermekeket magukat kérdezzük ki a saját világukról.

A posztmodern szemlélet szerint nem lehet egyetemes gyermekkorról, szemléletről beszélni. A sokféleség egyszerre van jelen gondolkodásunkban. A tudományos eredmények nem megkérdőjelezhetetlenek, a korábbiak helyett a plurális gyermekszemléletnek kell helyet adni a kutatói munkában is (Endrödy-Nagy, 2015). Ez a fajta plurális szemlélet a gyermekkorkutatásban fontos kutatói attitűdként van jelen.

\subsubsection{A Moszkvai Pszicholingvisztikai Iskola}

Kutatásunk nyelvészeti oldalát elsősorban a Moszkvai Pszicholingvisztikai Iskola keretében elért tudományos eredmények segítették, tanulmányunk elméleti hátterét is a moszkvai iskola teóriáira támaszkodva alakítottuk ki. A moszkvai szellemi-tudományos központ létrejötte 1966-ra tehető, ekkor indult a Leontiev (Leontiev, 1993) nevéhez köthető, nemzetközileg is nevet és elismerést szerző híres pszicholingvisztikai előadássorozat Moszkvában.

A moszkvai iskola a Vigotszkij-féle kulturális-történeti hagyományra támaszkodik (Vigotszkij, 1971), elméleti hátterének egyik axiomatikus feltételezése pedig, hogy a nyelvhasználó nyelvprodukciós és - percepciós tevékenységekor kettős nyelvi háttérrel rendelkezik és ezzel operál. Az ún. belső nyelv-külső nyelv közötti distinkciót Zsinkin így fogalmazza meg: „A belsö vagy fogalmi nyelv közvetitö szerepet tölt be az emberi elme tevékenységének végzésekor (pl. információk keresése és feldolgozása közben), és semmilyen kapcsolatban nem áll a világ egyik konkrét nyelvével sem. A külső vagy formális nyelvet a nyelvhasználó az egy adott kultúrához tartozó társaival való kommunikációra alkalmazza. E két »nyelv « együttes müködése alkotja a tudatosságként ismert jelenséget." (Zsinkin, 1982. 141. o., idézi Lfimtseva, 2014b. 2. o., Lénárt István fordítása).

Az angolszász hagyományra épülő európai szakirodalomban kevéssé ismert Moszkvai Pszicholingvisztikai Iskola, fennállásának több mint fél évszázada alatt számos, a nyelvészet, a kommunikációelmélet és az interkulturális kommunikáció területén hatékonyan alkalmazható elméletet és módszert dolgozott ki (Lénárt, 2019). Ezek közt említjük a verbális tudatosság terminus bevezetését 
(Tarasov, 1996), a lakúnaelmélet kidolgozását (Markovina, 2011), az asszociációs módszer (Ufimtseva, 2014a) bevezetését és annak szisztematikus alkalmazását interkulturális kommunikációs jelenségek kutatására, valamint nagyméretű asszociációs szótárak létrehozását mind orosz, mind egyéb (pl. francia, spanyol) nyelven.

A verbális tudatosságot mint az interkulturális kommunikáció kutatásának központi terminusát Tarasov így definiálja: „a tudatosság mentális képeiböl verbális úton externalizált összetett egész, amely magába foglalja az ember és tevékenységei fogalmát, illetve egy adott kultúra tagjai által kialakitott tárgyak és jelenségek fogalmát" (Tarasov 1996. 7. o., Lénárt István fordítása). A nyelvi tudatosság vizsgálatát a moszkvai iskola az asszociációs módszer segítségével valósítja meg: ennek során az adatközlők adott stimulus-szavakra reakció-szavakkal válaszolnak, olyan kifejezésekkel, melyek az adott stimulus hallatán (vagy láttán) elsőként eszükbe jutnak. Az így nyert nyelvi adatok egyes kultúrák vizsgálata mellett összehasonlító nyelvészeti kutatásokra is kiválóan alkalmazhatók.

Végül megemlítjük a szintén a Moszkvai Pszicholingvisztikai Iskola keretei között kidolgozott lakúnaelméletet (Markovina, 2011), amely a lefordíthatatlan - azaz célnyelvi ekvivalenssel nem rendelkező - nyelvi elemeket vizsgálja, ezek segítségével végez összehasonlító nyelvészeti vizsgálatokat.

\subsection{A nyelvhasználat és kulturális megközelités indulása}

Először Réger Zita mutat rá, hogy „a kisgyermek és a környezete közti beszédkapcsolat alakulása kulturálisan meghatározott", azaz más és más kultúrában máshogy jelenhet meg, sok minden befolyásolja a világképtől az etnikai normarendszeren, identitáson át a közösségi normarendszerig, a nyelv része a szocializációnak, kultúra és normarendszer átadásának (Réger, 1995. 97. o.), így érdemes lehet a szocializációs színterekre figyelmet fordítani, amikor gyermekek nyelvhasználatát vizsgáljuk.

Vigotszkij, aki a nyelvröl és gondolkodásról alkotott kulturális elméletet, rámutat, hogy a gyermekek nyelvi tapasztalásai azért szociális jellegűek, mert fejlődésük felnőttek környezetében valósul meg. A beszéd olyan belső dialóguson alapszik, melyben a gondolkodás és nyelv szoros kapcsolatban áll, a párhuzamos fejlődés a kettő közt pedig kétéves kor körül kapcsolódik össze, a gondolkodás verbálissá válásával (Vigotszkij, 1934/1987), így válik alkalmassá a szókincs és a gondolkodás vizsgálatára. Bár kutatásaik sok ponton eltérnek, Piaget felhívja a figyelmet arra, hogy a kisgyermek a müveletek előtti szakaszban, azaz 2-6 éves kora közt képesé válik arra, hogy a nem jelenlévő dolgokról, tárgyakról, eseményekről akkor is gondolkodjon, mikor azok nincsenek jelen (Piaget, 1929/1979).

\subsection{A 4-5 éves gyermekek nyelvhasználata}

Röviden összefoglalva a korosztály nyelvhasználati jellemzőit, a következőket tudjuk megállapítani:

- Képes a saját akaratát és érdeklődését kifejezni.

- Csoportokat és neveket használ, kiterjedt szókinccsel rendelkezik.

- Egyszerű magyarázatra képes és egyszerübb történetalkotásra.

- Egyszerü nyelvtani struktúrákat használ.

- Szabad játék alatt hangosan beszél.

- Megérti az egyszerü utasításokat.

- Folyamatosan növekvő szókincse van.

- Jelentéskeresés jellemzi és az új szavak hangjának megjegyzése.

- A stimuláló, motiváló környezet segíti a beszédfejlődését. (EYFS, 2007)

Korábbi vizsgálatok alapján kimutatható, hogy a korszakra a nyelvtani komplexitás gyors növekedése mellett a nyelvtani szabályok túláltalánosítása jellemző (Cole és Cole, 2003), mindezek miatt a középsős korosztály alkalmas lehet a lekérdezésre.

\section{Módszertani keretek}

\subsection{Szóasszociáció}

A nyelvi tudatosság vizsgálatának a Moszkvai Pszicholingvisztikai Iskola által leggyakrabban alkalmazott módszere a szóasszociációs módszer (Ufimtseva, 2014a), melynek keretében a válaszadók ún. stimulusszavakra 
Vállt vállnak vetve - gyerekek a gyermekkorról

reagálva nyelvi adatokat - válasz-reakciókat - közölnek. A reakciókat a kutató rögzíti, rendszerezi, gyakorisági sorrendbe rendezi, majd a gyakorisági listák alapján elemzi azokat.

A szóasszociációs módszer alkalmazása során a válaszadók azokkal a szavakkal reagálnak, melyek az adott stimulusszó alapján elsőként eszükbe jutnak. A módszer előnye egyszerüsége mellett abban rejlik, hogy segítségével nagyszámú anyanyelvi nyelvhasználó közvetlen lekérdezése válik lehetővé, továbbá, kiválóan alkalmazható mind eseti kutatások elvégzésére, mind egyes nyelvközösségekre, kultúrákra vagy országokra vonatkozó szóasszociációs szótárak (Orosz Nyelv Asszociációs Szótára, Szláv Asszociációs szótár, Edinburgh Asszociációs Tezaurusz, FranciaOrosz Asszociációs Szótár stb., Agykapocs Online Asszociációs Adatbázis) létrehozására (Karaulov et al., 2002; Cherkasova, 2014; Kiss et al., 1973; Debrenne, 2011; Lengyel, 2008; Kovács, 2013).

\subsection{Koragyermekkori kikérdezés}

Az ún. shoulder-to-shoulder, azaz vállt vállnak módszert a Griffin és kutatótársai (Griffin et al., 2016) írják le. A kutatócsoport saját 7-10 éves korcsoporttal végzett kutatása két módszerét a fent említettet, valamint a walk around - azaz sétáljunk körbe - metódusát elemzi. Mindkettő tanulságos, a vizsgálat leírása alapján hatékony lehet a 7-10 éves korosztállyal. Kutatócsoportunk a módszer alapos ismeretében, valamint a választott korosztályba tartozó 5 magyar gyermek lekérdezése után úgy döntött megfelelő lehet a kutatásban elvárt 100-100 fős minta eléréséhez is a vállt vállnak módszer.

A módszert először Meisinger említi 2004es olvasáskutatással foglalkozó vizsgálatában. Az olvasás folyékonyságát úgy vizsgálta, hogy maga mellé ültette a gyermeket és vállt vállnak vetve osztoztak a könyvön, miközben együtt olvasták azt (Meisinger et al., 2004, 117.). Griffin és társai megállapítják, hogy a módszer interjúszituációban a vizsgálatukban hasonlóan müködött, miközben együtt olvasgattak vagy osztoztak egy tárgyon, kiválóan tudtak beszélgetni és az interjút megvalósítani. A konkrét interjúszituációt úgy írják le, hogy hátukat a falnak támasztva, egymás mellett ültek, egy könyvtári könyvet nézegetve, válluk szinte összeért. A kutatók jelzik, milyen gazdag anyaghoz jutottak így hozzá, és ezt magának a módszernek tudták be. Az interjú flowt előidéző szituációja a szemkontaktus redukálása és az adott tárgyra való fókuszálás miatt valósulhatott meg véleményük szerint (Griffin et al., 2016). A kutatócsoport a diszkusszióban fogalmazza meg, hogy bizonyos életkori csoportoknál ez a módszer jól működhet. Kísérletként kutatócsoportunk úgy határozott, hogy a 4-5 éves korosztálynál könyv helyett a szabad játékból átvezetve, vagy rajzoláshoz kapcsolódva talán működhet a módszer. A lekérdezőknek azt az instrukciót adtuk, hogy szabadon játszó, vagy rajzoló gyermek mellé telepedjenek le, kezdjenek beszélgetni velük úgy, hogy hagyják, hogy a gyermek irányítsa a beszélgetést. Majd, amikor a gyermek kellően relaxált állapotban van, a kérdőív kérdésein haladjanak végig és minél pontosabban rögzítsék a gyermek válaszait.

\subsection{A kérdöív}

A kérdőív 27 kérdést tartalmaz és 10 stimulust jár körbe. A 10 stimulusból 5 a gyermek elsődleges és másodlagos szocializációs színteréhez köthető, ezek: barát, gyerek, család, otthon, játék; 5 pedig a fent felsorolt szóaszszociációs szótárakból, kutatócsoportunk korábbi kutatásaihoz kapcsolódóan volt kiválasztva: angyal, ördög, fekete, külföldi és a víz szavak esetében.

Minden stimulushoz, azaz értelmezni kívánt szóhoz minimum két kérdés kapcsolódik, mely értelmezi és környezetbe helyezi az adott szót a gyermekek számára könnyebbé téve az értelmezést. A felvezető kérdések minden stimulus esetében: Mi jut eszedbe arról, hogy.... Például a barát esetén: Mi jut eszedbe arról, hogy „barát”? vagy az angyal esetében: Mi jut eszedbe arról, hogy „angyal”? ezek a kérdések segítenek ráhangolni a gyermeket az 
adott szó és a hozzákapcsolódó fogalmi keret, érzések felidézésére. Az asszociációkat előhívó kérdéseket követik az adott szóval kapcsolatos kiegészítő kérdések. A barát és a család szó esetén konkrét személyekre is kérdezünk: Ki a barátod? Kik vannak a családodban? A harmadik kérdéstípus pedig leírásra ad lehetőséget: Milyen a víz? Milyen az ördög? Korábbi felnőttekkel folytatott a gyermekkép feltárására irányuló vizsgálatokban gyakran kérdeztünk úgy, hogy metaforákat gyüjthessünk (Endrödy-Nagy, 2013; Aggné Pirka és Endrödy-Nagy, 2016; Serfózö és Böddi, 2018), így ezt a kérdést a gyermekeknek is feltettük: A gyerek olyan, mint... (folytasd), szólt az instrukció.

\section{Néhány eredmény}

A következőkben a 10 stimulus közül a gyerek fogalmi körét és az eredményeket mutatjuk be. A vizsgálat számos univerzálét tárt fel, mely kultúrafüggetlenül mindkét lekérdezett csoportban előfordult. Így a gyermekek kimondják, hogy a „a külföldi beszél, utazik és él (a külföldi szó leggyakoribb igei asszociációi: beszél, utazik, él)"; "a család az anyáról, a jóságról és a szeretetről szól".

Számos esetben tártunk fel kultúrához, illetve nyelvhez köthető jellegzetességeket: a дpyz-дрyжumb a barát, illetve a barátból képzett ige, melynek jelentése: barátkozni, barátoknak lenni; а чёрт-чёрточка-чёрныцй: hasonló hangzású szavak, jelentésük: ördög/ pokol, vonal, fekete, ugyanakkor az ördög fogalmi kerete a magyar nyelv esetében nem ennyire bőséges.

A globalizáció hatásai is megfigyelhetőek: a játékszerek közül a gyermekek gyakran említik a tablet szót, azonos rajzfilmeket néznek Moszkvában és Budapesten pl. Miraculous Katica, termékeket és márkaneveket sorolnak fel például: Lego, Duplo, Ladybug (vö. gyerekek márkákat előhívó asszociációival kapcsolatban Kovács, 2019).

Több esetben fordítási anomáliákba ütközünk, mely alátámasztja a lakúnaelmélet jelenségét, például az ördög különböző le- hetséges fordításai: дьявол / чёрm / бес / сатана, melyek a fentebb említett tartalmat adhatják vissza az egyes fordításoktól függöen. A magyar ördög szó említett orosz ekvivalensei (дьявол / чёрm / бес / сатана) között jelentésárnyalatbeli, konnotációs különbségeket fedezhetünk fel, azonban mind a négy lexémát ördög-ként fordíthatjuk.

A szóbeli kikérdezés lehetőséget teremtett a gyermekek számára az elaborációra; sok gyerek a problémáiról mesélt, különösen az otthoni gondjairól olyanokról, mint például az apa halála vagy a szülők válása.

A vizsgálat megerősítette, hogy a gyermekek nem biztosak benne, hogy az angyal és ördög létezik, vagy sem, azaz a fikció és a valóság még nem elválasztható, a korosztályból néhányan kezdik felismerni és elkülöníteni, de csak kevesen biztosak a tudásukban.

A következőkben pillantsunk rá részletesebben a gyerek szó magyar és orosz változatára, a kutatás eredményére. A 2. ábrán a gyerek és а ребёнок ('gyerek') szavakhoz kapcsolódó említéseket és elemszámukat hasonlíthatjuk össze.

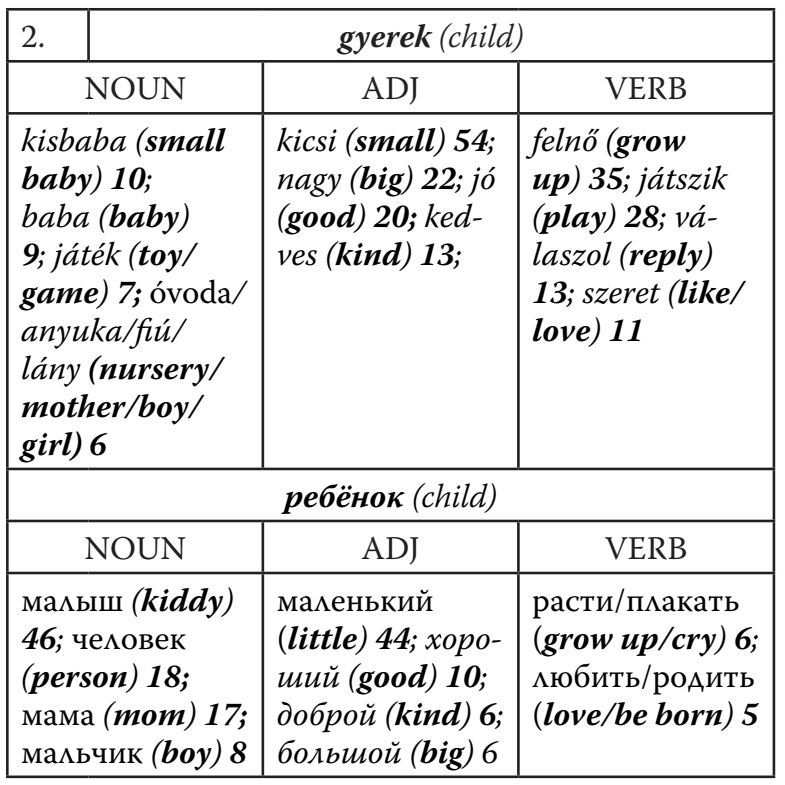

2. ábra: A gyerek és а ребёнок ('gyerek') szavakhoz kapcsolódó említések és elemszámuk

Elemzésünkhöz a Sketch Engine nevü szoftvert használtuk, mely lehetőséget teremt a korábbi asszociációs vizsgálatokkal való adatösszevetésre is. A Sketch Engine 
Vállt vállnak vetve - gyerekek a gyermekkorról

(Kilgarriff, 2014) egy online korpusznyelvészeti eszköz, melynek segítségével szavak milliárdjaiból álló korpuszok összehasonlítása válik lehetővé. Elemzésünk során a kutatás folyamán nyert nyelvi adatokat feltöltöttük a Sketch Engine rendszerébe, és a Sketch Engine elemzői funkciói segítségével elemeztük azokat.
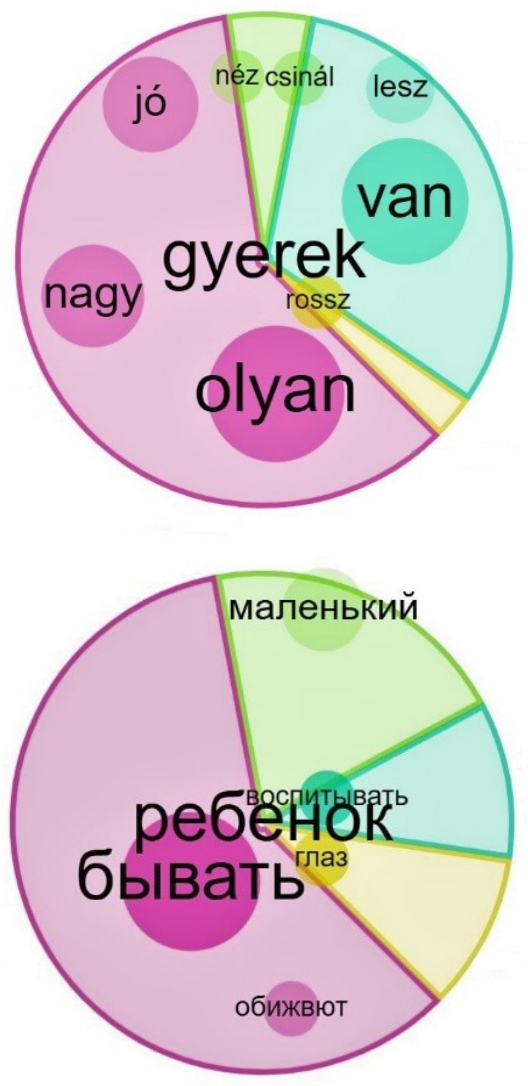

3-4. ábra: A gyerek és a ребёнок szavak elemzése a Sketch Engine szoftver segítségével. Orosz feliratok a jobb oldali ábrán: ребёнок (gyerek); воспитьвать (nő); обижают (bánt); бьıать (van); глаз (szem); маленкий (kicsi/pici).

A 2. ábra bemutatja a gyerek stimulusra kapott válaszokat és gyakoriságát a 100-100 válaszadó köréből. Az eredményeket főnév, melléknév és igék szerint csoportosítottuk.

Melléknevek: kicsi, kedves, jó - ezekkel a tulajdonságokkal azonosítják a gyermeket, azaz magukat, vagyis úgy tünik, hogy a gyermekségükre pozitívan reflektálnak.

Főnevek: gyüjtött szinonimák a gyerek szóra: baba, gyerkőc, mindkét csoportnál feltünik az anya, az apa viszont nem.
Igék: a felnőni és a szeretni említése szignifikáns mindkét nyelvhasználó csoportnál.

$\mathrm{Az}$ orosz említések: ребёнок (gyerek); воспитывать (nő); обижают (bánt); бывать (van), глаз (szem); маленкий (kicsi/ pici).

A magyar említések: gyerek, nagy, jó, néz, csinál, lesz, van, rossz, olyan.

Ezeket az említéseket segít térben is ábrázolni a választott szoftver, mely a 3-4. ábrán láthatóan a szavakat és környezetüket is megmutatja. Az eredményeket kategóriákba csoportosíthatjuk és nyelvtani relációkat állíthatunk fel, tárgyat, alanyt vagy például módosítószókat kereshetünk.

Végezetül érdekességképp álljon itt a 15 leggyakrabban említett szó a két vizsgált csoportban (ld. 5. ábra).

\begin{tabular}{|c|c|c|c|c|}
\hline & \multicolumn{2}{|c|}{ Hungarian (HU100) } & \multicolumn{2}{|c|}{ Russian (RU100) } \\
\hline & word & freq & word & freq \\
\hline 1. & én $(I)$ & 228 & $\mathrm{OH}(\boldsymbol{h e})$ & 161 \\
\hline 2. & ö (he/she) & 194 & $\begin{array}{l}\text { мама } \\
\text { (mother) }\end{array}$ & 158 \\
\hline 3. & $\begin{array}{l}\text { anya } \\
\text { (mother) }\end{array}$ & 145 & я (I) & 144 \\
\hline 4. & $\begin{array}{l}\text { gyerek } \\
\text { (child) }\end{array}$ & 129 & папа (father) & 136 \\
\hline 5. & apa (father) & 118 & $\begin{array}{l}\text { махенький } \\
\text { (small) }\end{array}$ & 117 \\
\hline 6. & $\begin{array}{l}\text { játék (game) } \\
\text { toy) }\end{array}$ & 111 & $\begin{array}{l}\text { человек } \\
\text { (person) }\end{array}$ & 103 \\
\hline 7. & $\begin{array}{l}\text { barát } \\
\text { (friend) }\end{array}$ & 77 & $\begin{array}{l}\text { АOM (house/ } \\
\text { home) }\end{array}$ & 75 \\
\hline 8. & mi (we) & 76 & $\begin{array}{l}\text { играть } \\
\text { (play) }\end{array}$ & 69 \\
\hline 9. & $\begin{array}{l}\text { család } \\
\text { (family) }\end{array}$ & 58 & малыш (kid) & 54 \\
\hline 10. & ház (house) & 58 & мы (we) & 53 \\
\hline 11. & ök (they) & 54 & $\begin{array}{l}\text { большой } \\
\text { (big) }\end{array}$ & 50 \\
\hline 12. & $\begin{array}{l}\text { anyuka } \\
\text { (mother) }\end{array}$ & 53 & Аруг (friend) & 47 \\
\hline 13. & $\begin{array}{l}\text { ruha } \\
\text { (clothes) }\end{array}$ & 52 & $\Lambda ю б \Lambda ю($ love) & 47 \\
\hline 14 . & víz (water) & 48 & $\begin{array}{l}\text { бемый } \\
\text { (white) }\end{array}$ & 47 \\
\hline 15. & szárny (wing) & 46 & $\begin{array}{l}\text { хорошая } \\
\text { (good) }\end{array}$ & 45 \\
\hline
\end{tabular}

5. ábra: A 15 leggyakrabban említett szó 


\section{Diszkusszió}

Jelen tanulmányban a vizsgálat módszertanára fókuszálunk, így diszkussziónkban is arra keressük a választ vajon megfelelő-e módszertanunk a 4-5 éves korcsoport vizsgálatára. Fontos hangsúlyozni, hogy a viszonylag kis minta kvaltitatív kutatásunk esetén mélyfúrásra alkalmasnak bizonyult. Az egyes stimulusok megértését szavanként 2-4 kérdéssel jártuk körbe, ezzel biztosítva, hogy a résztvevő lekérdezett gyermekek biztonsággal számot adhassanak a fogalom ismeretéről és számukra a stimulus fogalmi hátteréről, értelmezéséről, jelentéséről. Korábbi shoulder-toshoulder vizsgálatok idősebb gyermekekkel és elsősorban tudásszint felmérésre irányulva zajlottak. Jelen kutatás a középsős korosztály bevonásával lényegesen fiatalabb gyermekek bevonásával zajlott és a nyelvi tudatosságukra irányult - nem konkrét tudásszintre, inkább a gondolkodás megértésére.

\section{Konklúzió és a továbblépés irányai}

A konklúzióban fontos kiemelni, hogy a gyermekek saját magukat a felnőttek kicsi változataként írják le, sokszor hasonlítják magukat kisállatokhoz, olyan szavakat használnak, mint például a nyuszika, vagy a medvebocs.

Érdemes megemlíteni, hogy a gyermekkorkutatás központi kérdése és dilemmája, illetve arra rímelö eredmények kerülnek felszínre, ami nem más mint, hogy „A gyermek isteni vagy ördögi lény?” (Heywood, 2001). Kutatási eredményeinkben a gyermek elsődleges asszociációi mindkét nyelvhasználó csoportban a jó és a szép.

A gyermekek a játékot és játszást kizárólagos gyermeki normának tekintik, a gyermeket a felnőttől az különbözteti meg, hogy ez utóbbi nem játszik.

Végül, de nem utolsó sorban le kell szögeznünk, hogy a kutatási eredmények további elemzésére is szükség van. Terveink közt szerepel a kognitív nyelvészeti szempontok, például lehetséges metaforák elemzése. További kutatásokra van szükségünk, mert egyértelmüen látszik, hogy a gyermekek óriási tudás- sal rendelkeznek az őket körülvevő világról már 4-5 éves korukban és tudásuk az érintett témákban is nagyobb, mint arra a kérdőív összeállításakor kutatócsoportunk tagjai számítottak. Tervezzük továbbá a kutatást további célországokkal, kultúrákkal bővíteni, a tervek között jelenleg Japán és Laosz szerepel. A vizsgálat során felmerült, hogy elvont fogalmakat, mint a boldogság, születés, halál vagy a szerelem is lehetséges lenne hasonló módszerekkel, kellő óvatossággal körüljárni.

\section{Felhasznált irodalom}

Aggné Pirka Veronika és Endrődy-Nagy Orsolya (2015): A 20-21. század fordulójának gyermekképe a tanítók szemszögéből. In: Tóth Péter, Holik Ildikó és Tordai Zita (szerk.) Pedagógusok, tanulók, iskolák - az értékformálás, az értékközvetités és az értékteremtés világa: tartalmi összefoglalók: XV. Országos Neveléstudományi Konferencia. Budapest, Óbudai Egyetem.

Aggné Pirka Veronika és Endrődy-Nagy Orsolya (2017a): Vélekedések a nevelésről és a nevelhetőségről óvodapedagógusok körében. (1. rész). Óvodai Nevelés, 70. 8. sz., 16-17.

Aggné Pirka Veronika és Endrődy-Nagy Orsolya (2017b): Vélekedések a nevelésről és a nevelhetőségről óvodapedagógusok körében. (2. rész). Óvodai Nevelés, 70. 9. sz., 28-30.

Alderson, P. (2013): Childhoods real and imagined, Volume 1: An introduction to critical realism and childhood studies. Routledge, Taylor and Francis Group, Oxon, GB - New York, USA.

Benko, V. (2014): Compatible Sketch Grammars for Comparable Corpora. In: Abel, A., Vettori, Ch. \& Ralli, N. (Eds.) Proceedings of the XVI EURALEX International Congress: The User In Focus. 15-19 July 2014. Eurac Research, Bolzano/Bozen, 417-430.

Cherkasova et. al (2004): Szláv Asszociációs Szótár: orosz, belorusz, bolgár, ukrán nyelvekre, Nyelvtudományi Intézet, Orosz Tudományos Akadémia, Moszkva.

Christiansen, P. \& James, A. (2000): Researching Children and Childhood: Cultures of Communication. Routledge Falmes, Taylor \&Francis Group, Oxon, GB.

Cole, M. és Cole, Sh. R. (2006): Fejlődéslélektan, Osiris kiadó, Budapest. 
Vállt vállnak vetve - gyerekek a gyermekkorról

Debrenne M. (2011): French Associative Dictionary (Французский ассоциативный словарь), Novosibirsk, NGU.

Endrődy-Nagy Orsolya (2013): Óvodapedagógus-hallgatók gyermekképe és értékrendje. In: Kurucz Rózsa (szerk.) Hidak és párhuzamok a 175 éves közép-európai és magyarországi óvóképzés történetében. Pécsi Tudományegyetem Illyés Gyula Kar, Szekszárd, 253-265.

Endrődy-Nagy Orsolya (2015): A reneszánsz gyermekképe - a gyermekkép reneszánsza, Eötvös Kiadó-TEPA, Budapest.

The Early Years Foundation Stage (2007): Department for Education and Skills, London.

Frickel, S., Albert, M. \& Prainsack, B. (2017, eds.): Investigating interdisciplinary collaboration, Theory and Practice across disciplines, Rutgers University Press, New Brunswick.

Golnhofer Erzsébet és Szabolcs Éva (2005): Gyermekkor: nézöpontok, narratívák. Eötvös József, Budapest.

Griffin, M., Lahman, M. \& Opitz, M. (2014): Shoulder-to-shoulder research with children: Methodological and ethical considerations. Journal of Early Childhood Research, 14. 1. SZ., 18-27.

Hendrick, H. (2000): The Child as a Social Actor in Historical Sources Y: Problems of Identification and Interpretation. In: Christensen, P. \& James, A: (eds.), Research with Children: Perspectives and Practices. Falmer Press, London, 36-61.

Heywood, C. (2001): A History Of Childhood. Blackwell, Malden, USA.

James, A. \& Prout, A. (1997, eds.): Constructing an Reconstructing Childhood: Contemporary Issues in the Sociological Study of Childhood. Falmers Press, Taylor \& Francis Group, London, Washington, D.C.

Karaulov Ju. N., Cherkasova G. A., Ufimtseva N. V., Sorokin Ju. A. \& Tarasov E. F. (2002): Russkij associativnyj slovar' (RAS) [Russian associative dictionary (RAS)]. T.1, 2. M.: AST-Astrel'.

Karaulov, Yu. N. (2011): Semanticheskiy gestalt assoziativnogo polya $i$ obrazy soznaniya [Semantic gestalt of an associative field and images of consciousness]. Yazykovoye soznanie $i$ funkzionirovanie [Verbal consciousness: contents and functionality]. Institut Jazikoznaniya RAN, Moscow, 107-108.
Kilgarriff, A., Baisa, V., Bušta, J., Jakubíček, M., Kovář, V., Michelfeit, J., Rychlý, P. \& Suchomel, V. (2014): The Sketch Engine: ten years on. Lexicography, 1, 1. sz. 7-36.

Kiss, G., Armstrong, C., Milroy, R. \& Piper, J. (1973): An associative thesaurus of English and its computer analysis, In: Aitken, A. J., Bailey, R. W. \& Hamilton-Smith, N. (Eds.),The Computer and Literary Studies. Edinburgh University Press, Edinburgh, 153-165.

Kovács László (2013): Fogalmi rendszerek és lexikai hálozatok a mentális lexikonban. Tinta Konyvkiadó, Budapest.

Kovács László (2019): Márkák, asszociációk és fogyasztás - változások a társadalom átalakulásának tükrében. Alkalmazott Nyelvtudomány. 19. 1. sz., 1-17.

Lenart, I. (2019): An introduction to the Moscow School of Psycholinguistics through Mikhail Bulgakov's novel: The Master and Margarita, In: Bátyi Szilvia (szerk.) A nyelv tanitás, tanulás, reprezentáció, feldolgozás, Pszicholingvisztikai tanulmányok VI. Pannon Egyetem MFTK, Veszprém, 240-249.

Lengyel Zsolt (2008): Magyar asszociációs normák enciklopédiája I. Tinta Konyvkiadó, Budapest.

Leontiev, A. A. (1993): Jazikovoje soznanie i obraz mira [Language consciousness and the image of the world]. Yazyk $i$ soznanie: Paradoksalnaya ratsionalnost [Language and consciousness: Paradoxical rationality]. Institut Jazikoznania RAN, Moscow, 16-21.

Markovina I. Yu. (2011): Teoriya lakun v issledovanii problem mezhkulturnogo obscheniya. Etnopsiholingvisticheskiye osnovy lakunologii [Lacuna theory in studying intercultural communication issues. Ethnopsycholinguistic bases of the lacuna theory]. LAP LAMBERT Academic Publishing.

Meisinger, E., Schwanenflugel P., Bradley B. et al. (2004): Interaction quality during partner reading. Journal of Literacy Research, 36. 2. sz., 111-140.

Mészáros György (2010): Metodológiai kérdések és alkalmazott neveléselmélet. In: Szabolcs Éva (szerk.) Neveléstudomány - reflexió innováció. Az ELTE PPK Neveléstudományi Intézet 2010. április 16-án tartott konferenciájának elöadásai, Gondolat, Budapest. 240-252. 
Nóbik Attila (2000): Kísérlet a gyermekkép fogalmának meghatározására. Magyar Pedagógia, 100. 3. sz., 367-376.

Piaget, J. (1929/1979): The child's conception of the world. Harcourt Brace, New York.

Réger Zita (1995): A nyelvi fejlődés. In: Bernáth László és Solymosi Katalin (szerk.) Fejlödéslélektan szöveggyüjtemény, ELTE TFK, Budapest.

Russian Association Dictionary. (1986-1996). (Russkij Assoziativnij Slovar'), URL: http://www.tesaurus.ru/dict/dict.php, (Accessed: Febr. 2019).

Scherba L. V. (1974): Yazykovaya sistema $i$ rechevaya deyatelnost' [Language system and speech activity]. Nauka, Leningrad.

Serfőző Mónika és Böddi Zsófia (2018): A „hópehely" és a "varázsló" - kisgyermeknevelö-, óvodapedagógus- és tanítójelöltek szerepértelmezése. In: Endrődy-Nagy Orsolya és Fehérvári Anikó (szerk.) Innováció, kutatás, pedagógusok, HERA Évkönyvek V., HERA Debreceni Egyetem, Budapest-Debrecen.

Sergieva, N. S. (2006): Semanticheskiy gestalt i yadro yazikovovo soznaniya russkih [Semantic gestaltand the core of Russians' verbal consciousness] Vestnik YuUrGU. Social Sciences and Humanities. 57. 2. sz, 160-165.

Sokolova, T. V. (1998): Assoziativny tezaurus rebyonka 3-6 let [Associative thesaurus of a 3-6-year-old child]. Nauchny doklad uch. step. doktora nauk. Astrakhan.

Sorokin, J. A. (1993): Die Lakunen-Theorie. Zur Optimierung interkultureller Kommunikation. In: Ertelt-Vieth, A. (Hg.) Sprache, Kultur, Identität. Selbst- und Fremdwahrnehmungen in Ost- und Westeuropa. Peter Lang, Frankfurt am Main, 163-173.

Szabolcs Éva (2003): Gyermekkortörténet: új elméleti megfontolások. In: Pukánszky Béla (szerk.) Két évszázad gyermekei. Eötvös József, Budapest, 9-17.

Tarasov, E. F. (1996): Mezhkulturnoye obscheniye - novaya ontologiya analiza yazykovogo soznaniya [Intercultural communication is a new ontology to analyze verbal consciousness]. Etnokulturnaya spezifika yazykovogo soznaniya [Ethnocultural peculiartities of verbal consciousness], 7-22.

Tarasov E. F. (1996): Jazikovoje soznanije - perespektivi issledovanija [Language conscious- ness - research perspectives]. Etnokulturnaja spetsifika yazykovogo soznaniya [The ethnocultural specificity of language consciousness], 7-22.

Goldin V. E., Martyanov A. O. \& Sdobnova A. P. (2008, szerk.): The digital Russian associative dictionary of schoolchildren (Elektronnij Russkij assoziativnyj slovar shkolnikov), Saratov State University named after Chernishevskovo, Saratov.

Ufimtseva, N. V. (2006): Etnopsicholingvistika: vchera i segodnya [Ethnopsycholinguistics: yesterday and today]. Voprosy psiholingvistiki [Journal of Psycolinguistics], 4., 92-100.

Ufimtseva N. V. (2009): Obraz mira russkikh: sistemnost' i soderzhaniye [Image of the world of Russians: the systemic characteristics and the content]. Yazik $i$ kultura [Language and culture], 4. 8. sz., 98-111.

Ufimtseva, N. V. (2011): Yazykovoye soznaniye: dinamika i variativnost' [Verbal consciousness: dynamics and variability]. Institut Jazikoznaniya RAN, Moscow.

Ufimtseva, N. (2014a): The Associative Dictionary as a Model of the Linguistic Picture of the World. Procedia - Social and Behavioral Sciences, 154., 36-43.

Ufimtseva, N. (2014b): Russian Psycholinguistics: Contribution to the Theory of Intercultural Communication. Intercultural Communication Studies, 23. 1. sz., 1-13.

Ushakova, T. N. (2003): Yazykovoye soznaniye I prinzypy ego issledovaniya [Verbal consciousness and the principles of its research]. Yazykovoye soznanie $i$ tekst: teoreticheskiye i prikladnye aspekty [Verbal consciousness and text: theoretical and practical aspects] 6-17.

Vasilevich, A. P. (1987): Issledovanie leksiki v psiholinvistiveskom eksperimente [Studying language in a psycholinguistic experiment]. Nauka, Moscow.

Vigotszkij, L. (1971): A magasabb pszichikus funkciók fejlődése; ford. Ujhelyi Gabriella; Gondolat, Budapest.

Vygotsky, L. S. (1934/1987): Thinking and speech. In: Minick, T. N. (ed.) The collected works of L.S. Vygotsky. Vol. 1: Problems of general psychology. Plenum, New York. 


\section{Shoulder-to-shoulder - children about the childhood}

Our empirical, interdisciplinary and comparative research has been conducted since 2018 with 4-5-year-old Russian and Hungarian kindergarteners, focusing on understanding their conception of childhood and their verbal consciousness. The research is based on two disciplinary fields - Psycholinguistics and Early Childhood research, furthermore, the methodology and the theoretical background builds on these two fields. Our methodology called on the one hand the shoulder-to-shoulder method (Griffin et al. 2014) and on the other hand the association experiment. In the theoretical background, we must mention the Moscow School of Psycholinguistics and the Conception of Childhood narrative as the starting points of the research. The research has been conducted in parallel in Moscow and Budapest, led by our research group, which after the 4-5-year-old respondent group has already started investigating the 10-12-year-old group as well. The research was funded by the Russian Foundation for Basic Research so called RFFI. This paper examines the methodology of the research.

Keywords: association experiment, Psycholinguistics, shoulder-to-shoulder method, conception of childhood, early childhood

Endrődy Orsolya, Lénárt István és Irina Markovina (2019): Vállt vállnak vetve - gyerekek a gyermekkorról. Gyermeknevelés, 7. 2-3. sz., 125-135. 